$12-2021$

\title{
Long Haulers: The US Airline Industry and Moving Forward From the Covid-19 Pandemic
}

James Norman

University of North Dakota, james.e.norman@und.edu

How does access to this work benefit you? Let us know!

Follow this and additional works at: https://commons.und.edu/avi-fac

Part of the Aviation Commons

\section{Recommended Citation}

James Norman. "Long Haulers: The US Airline Industry and Moving Forward From the Covid-19 Pandemic" (2021). Aviation Faculty Publications. 8.

https://commons.und.edu/avi-fac/8

This Book Chapter is brought to you for free and open access by the Department of Aviation at UND Scholarly Commons. It has been accepted for inclusion in Aviation Faculty Publications by an authorized administrator of UND Scholarly Commons. For more information, please contact und.commons@library.und.edu. 


\title{
Long Haulers: The US Airline Industry and Moving Forward From the Covid-19 Pandemic
}

\author{
James Norman, Ph.D. Candidate \\ The John D. Odegard School of Aerospacce Sciences \\ The University of North Dakota \\ Grand Forks, USA \\ james.e.norman@und.edu
}

\begin{abstract}
As a subset of the global aviation industry, the United States has endured similar challenges as other countries, necessitating continual adaptation during the Covid-19 pandemic. This report shall highlight aspects of the pandemic recovery particular to the US aviation sector, acknowledging the nature of our interconnectedness as an industry. All stakeholders have opportunities to learn from each other and gain future agility as the industry attempts to recover from the direst crisis in its history.
\end{abstract}

Keywords-air cargo, aviation safety, Covid-19, ICAO, passenger misconduct, SMS, sustainability

\section{INTRODUCTION}

Undoubtedly, the Covid-19 pandemic is the most significant event to befall human society in modern times. Every facet of humanity is affected in some manner. Because of the unexampled nature of the virus, the disruptive nature of its impact revealed both resiliency and brittleness across all strata of infrastructure, logistics, and interconnectedness on a global level.

Perhaps no sector was more affected - and will be affected long-term - than commercial aviation. Because aviation inhabits a space at the nexus of economics, politics, geography, and technology, it finds itself in a bewildering state of competing interests. This is even more pronounced given the existential nature of the threat; unlike terrorist activity a virus is invisible, yet the destruction left in its wake is equally if not more catastrophic. Creating visual security barriers like the Transportation Security Administration (TSA) post-September 11 th signaled action by the government and aviation industry. What will the reaction be two decades later? Airlines that successfully anticipate what the future will look like post Covid will obtain both operational and economic advantages over competitors.

The resounding challenge will be in sensemaking what is transitory versus permanent. Only hindsight will bring clarity to the myriad complex issues that hindered an efficient response to the pandemic and offer lessons for us moving forward. Deeply profound ethical dilemmas will need to be addressed relating to access of medical care, vaccines, personal health surveillance, and habitation of the social space - issues that are entwined with, but also transcend the aviation industry.

This article will offer a US perspective. Given the general uniformity of the global aviation industry, the majority of issues that the US will face going forward are the same as the rest of the world. Therefore, the aim of this contribution is to raise issues that may be of particular significance or consequence as it pertains to the US, acknowledging that the nature of global commercial aviation is inextricably intertwined. First, a brief discussion about past historical disruptive events will be addressed, followed by an assessment of issues raised during the pandemic. Finally, future considerations will be discussed and recommendations to the industry put forth.

\section{HistORICAL CONTEXT}

The majority of disruptive events the aviation industry has experienced have been induced by way of accidents. The lessons learned from accident causal factors have helped to drive current aviation safety standards to an unprecedented level. However, events with political genesis extraneous to the industry have prompted significant changes within the industry as well:

- A spate of more than 100 hijackings between 1968-1972 prompted physical security screening of passengers at US airports in 1973

- The Airline Deregulation Act of 1978 gave rise to the hub and spoke network strategy, as well as paradoxically reduced competition in the marketplace-today, four airlines control $84 \%$ of the US market (Abate et al., 2020);

- The firing of nearly all air traffic controllers in 1981 by president Ronald Reagan was perhaps the most significant government-sanctioned anti-labor action in over a century (Shostak, 2006), and was a catalyst for future use of replacement workers in airlines (McCartin, 2006), as well as organizational restructuring despite profitability, resulting in depressed wages and work rules for air traffic controllers (Traynor \& Fichtenbaum, 1997) 
- September 11th, 2001 was seen as a "failure of imagination" (Patalano, 2017, p. 11). Its after effects both within aviation and geopolitically are still being felt today.

While the aforementioned events were physically salient, the past two decades have witnessed viral epidemics that affected aviation as well. The Severe Acute Respiratory Syndrome (SARS) outbreak of 2003 (Chung, 2015), Avian Flu of 2006 (Abeyratne, 2006), Swine Flu of 2009, Avian Flu of 2013, Ebola of 2014 (Cenciarelli et al., 2014) and MERS of 2015 all witnessed disruption to passenger travel. However, travel patterns generally took on a V-shaped recovery pattern and returned within six months (IATA, 2020b). These outbreaks also tended to be regional and did not rapidly proliferate as did Covid-19. Given the frequency of previous outbreaks, it is credible to state that we failed to imagine and prepare for a pandemic on the scale of Covid-19. As such, research is beginning to emerge in effort to benchmark Covid-19 against these past pandemics (see Fedorik, 2021).

\section{THE PRESENT}

Five topics will be presented relating to the Covid-19 pandemic, and their impact on US aviation.

\section{A. Economic Impact}

Regulatory agencies and trade organizations have done a commendable job in documenting the economic impact of the Covid pandemic (see Airlines for America, 2021; U. S. Government Accountability Office, 2021), and a thorough review is beyond the scope of this article. However, there are economic aspects that are unique to the US airline industry that will be highlighted.

The Coronavirus Aid, Relief, and Economic Security (CARES) Act, was passed by Congress and signed by the president into law on March 27th, 2020 (Tang, 2020). This omnibus package provided $\$ 2$ trillion dollars in overall relief, of which approximately $\$ 40$ billion dollars was allocated to the aviation sector. From this, \$32 billion dollars was allocated directly for payroll support programs, including $\$ 25$ billion to passenger air carriers and $\$ 5$ billion to cargo carriers. The Act stipulated that carriers could not involuntarily layoff or furlough employees, and also stipulated that stock buybacks and executive compensation would be prohibited. Nearly all passenger airlines participated in the Act, including United Airlines, American Airlines, Southwest Airlines, and Delta Air Lines (Bartle et al., 2021). Oversight of the Act has concluded that airlines were responsible stewards of the money allocated.

Similar action was taken across the Atlantic in Europe, where the notion of flag carriers still exists. Air France-KLM, Lufthansa AG and the TUI Group received comparable amounts as their US counterparts by the European Commission. However, unlike in the US, the aid provided to European airlines was met with consternation by non-flag, and flags-ofconvenience carriers, who accused the European Commission of illegal subsidization (Haines, 2021). The US likely avoided this debate, as it has not supported a flag carrier since the days of PAN AM many decades ago (Van Doren, 1993).

Another development to watch will be to see if economic belt-tightening prompts low-cost carriers (LCCs) in the US start to move towards a European model of operating heavy aircraft on longer routes, as does Vueling and Level over the transatlantic. Failed ventures like Wow Air and the long-haul iteration of Norwegian Air International (NAI) point to a precarious business model for long haul LCCs, for certain. However, jetBlue recently started service into London's Heathrow Airport, which has been the first foray into Europe by an American LCC.

A final economic consideration is that of the divergence between leisure and business travel. As the pandemic necessitated an abatement of business travel (e.g. Becken \& Hughey, 2021), US airlines are collectively holding their breath to see if and when business travel demand resumes. If business travel is slow to restart, US airlines may have to rethink their strategy in recent years of upgauging first-class amenities and charging ancillary fees (Derudder \& Witlox, 2016). Instead, they may find themselves removing middle-tier seating and catering towards more leisure class fares, as evidence is emerging that leisure travel demand has returned at a much more robust pace (Suau-Sanchez et al., 2020).

\section{B. Regulatory Impact}

As Safety Management Systems (SMS) have been adopted and made mandatory by regulatory authorities in recent decades, one of the major impacts has been a shift away from prescriptive standards to that of performance standards (Sønderby, 2016). The Covid-19 pandemic necessitated the Federal Aviation Administration (FAA) to shift many of its activities away from the front line, as well as grant waivers that would allow aviation to continue to operate in a reduced capacity (FAA, 2021c). This included extending pilot landing currency requirements, extending duration of medical certificates, and amending hours of air traffic control towers.

As we reflect on this flurry of activity generally lessening regulatory requirements, it follows that we should question the veracity of these regulations to begin with. If no degradation or compromise of safety was observed in our data, should we arbitrarily return to a pre-Covid regulatory environment? Or should we fully embrace a performance-based system, where the evidence drives changes to our SMS? Scholars have urged the adoption of evidence-based safety management (Rae et al., 2020), and this is an opportune time for academia to pragmatically influence practitioners.

\section{Safety Management Programs}

As corporate workspaces closed as a result of the pandemic, a decentralization occurred in aviation safety management. That issue of data security was elevated (Babbs, 2020), as 
employees working from home accessed company intranet platforms and participated in virtual meetings.

The safety programs that serve as the backbone for data ingestion at US airlines - the Aviation Safety Action Program (ASAP) and the Flight Operational Quality Assurance (FOQA) program - had to adapt quickly. ASAP participants shifted to virtual meetings to disseminate reports, and FOQA analysts needed to access flight data files off-site. Aided by a vast reduction in aircraft operations, US airlines generally exhibited resilience in keeping these essential programs running.

Interestingly, both ASAP and FOQA were undergoing a paradigm shift in 2020, concurrent to the stresses that the Covid-19 pandemic was exhibiting. The pandemic likely altered the trajectory of these programs.

In August of 2020, the FAA issued an updated Advisory Circular to the ASAP, notably including language that all reports were to be included upon submission, as well as participation by the FAA event review committee member to be optional in the case of sole-source events (FAA, 2020). Historically, the event review committee consisted of a threelegged stool: labor union, company, and the FAA. Now, not only were safety reports being processed remotely, but the FAA was only required to be present for a small portion of the meetings, as approximately $90 \%$ of reports an airline receives are of a sole-source nature (FAA, 2021a). This resulted in labor and airlines seemingly having a disproportionate influence on the outcome of reports. It has yet to be investigated if this has also resulted in a loss of information sharing with the FAA, and a consequent lessening of safety standards in the US.

Turning to flight data monitoring, 2020 saw the mandate of ADS-B transponders for most commercial aircraft in the US. As a result, a vast amount of flight data information-whose provenance had been historically tightly controlled and monitored by airlines - was free and available on open-access platforms, accessible to all. Public observers could now monitor flight parameters with close to the same fidelity as employees of the airline. This ubiquity of data availability happened concurrently with the decentralization of flight safety departments due to Covid, raising issues that have yet to be resolved. Of principal concern is the functional notion that the labor union is the "gatekeeper" of access to identified flight data; given rapidly developing trends, and the intrusion of outside forces brought about by Covid such as contact tracing, is it truly possible for this gate to be kept so tightly guarded? This issue should be at the forefront for airlines and labor unions in a post-Covid flight data world.

Lastly, an unfortunate consequence of the pandemic has been the stoppage of large-scale aviation safety information sharing conferences. Historically held twice a year and attended by over 1000 individuals, the FAA Infoshare conference is a multi-day affair that allows all types of operators - from major airlines to small Part 91 entities - the ability to share data in a protected environment. Because of the highly sensitive nature of the information shared, this type of conference is only possible in-person. The Infoshare conference is understandably a flagship for the just culture philosophy promoted by the FAA, and its resumption will be imperative as the industry recovers from the consequences of the pandemic.

\section{The Air Cargo Sector}

By and large, the air cargo industry proved to be resilient during the pandemic's downturn (Sun et al., 2021). As 50\% of air cargo is transported in the belly of passenger aircraft (Wiesner, 2021), it was inevitable that the passenger aircraft capacity reduction would have a negative impact on cargo capacity. However, as a result of capacity reduction, the cost of cargo shipping skyrocketed by $30 \%$, and resulted in one of the strongest financial performances by US cargo carriers during an economic downturn (IATA, 2020a).

The rise of e-commerce during the pandemic was clearly the foremost precipitator for air cargo demand. Online shopping became a diversion for some, and a necessity for others. Long lines at retail stores and empty shelves of toilet paper became a symbol early on in the pandemic of the fragility of the US supply chain. Unlike pre-Covid, where online purchases tended to be of a boutique or ancillary nature, consumers gravitated toward staples for living that would provide sustenance during months in quarantine (Bhatti et al., 2020). In fact, online shopping became imbedded in many of our daily routines (Abiad et al., 2020) and habituated consumers to its ease and immediacy. For the US, the archetype for this boom was Amazon, a company that leveraged the pandemic to more than double its annual profit (Weise, 2021) cementing its position with Apple, Google, Microsoft and Facebook as a Tech Giant (Herrman, 2019).

Perhaps no place was air cargo's success more pronounced during the pandemic than in the expansion of Amazon's lesserknown subsidiary, Amazon Air. While the US economy was shedding jobs and entering recession, Amazon built a $\$ 1.5$ billion dollar sorting facility in Cincinnati, Kentucky. This created 2000 jobs and helped the airport trend in a positive direction after years of decline in passenger travel revenue (Salerno, 2017). Amazon expanded its fleet of primarily Boeing 767 air freighters to 73 -operated by six separate airlines conducting around 200 flights a day (Lee, 2021). The business model perfected by Amazon from point of sale to last mile delivery during the pandemic is considered a viable template for global logistics as well, aiding in distribution of future demands such as disaster relief (Findlay et al., 2021).

Given the increased importance in the air cargo sector that the Covid-19 pandemic has provided, it is appropriate to reexamine the regulatory dichotomy that exists in the US between passenger and air cargo carriers. Soon after the most recent crash of a commercial passenger airliner in the United States in 2009, a spate of regulatory action was taken (Landsberg, 2014). 
This included new pilot qualification rules, improvement to pilot training record retention, and a science-based recalibration of flight time/duty time standards for pilots (Gibbs, 2014). However, this rule omitted cargo carriers from most of regulations, in what became to be known as the "cargo carveout" (Baas, 2020).

In the ensuing decade, debate has been lively between labor and industry on the issue. The world's largest pilot union-the United States' Air Line Pilots Association-argues that "science has yet to discover any biological differences between pilots who fly passengers and ones who fly all cargo" (ALPA, 2019); the industry in contrast claims the carveout "allowed the flexibility needed for air cargo operators to efficiently maintain their business models... including those related to the Covid-19 pandemic" (Baas, 2020, p. 2). The US has witnessed two significant cargo airline crashes in recent years: UPS on approach to Birmingham, Alabama in 2013, and Atlas Air on approach to Houston, Texas in 2019 (NTSB, 2019; Wilson, n.d.). However, due to the cost-benefit analysis relied upon by the FAA for the rulemaking process (Van Wee \& Roeser, 2013), little inertia has been seen to include cargo airlines and update safety standards, despite the increased accident rate in cargo operations. The rapid rise of Amazon Air during and post Covid pandemic suggests reconsideration of this situation is overdue.

\section{E. Passenger Issues}

In 2021 alone, the FAA received nearly 4,000 reports of unruly passenger behavior, the vast majority of which pertain to passengers refusing to comply with the US's federal face mask mandate (FAA, 2021d). Of these, 540 cases have resulted in formal enforcement action, with penalties ranging from costly fines to proposed jail time (FAA, 2021b). Research has yet to be published regarding systemic reasons for the contagion of passenger misbehavior, However, evidence is emerging that flight attendants have reached a tipping point with tolerance of violent behavior in the close confines of an aircraft cabin (McLinton et al., 2020; Wood, 2021). The FAA has stated publicly a "zero tolerance" policy towards mistreatment of flight crews as well. It will be interesting to see if unruly passenger behavior is merely a lagging indicator from the stress brought on by the Covid pandemic, or indicative of a new reality flight crews will face in the skies.

Passengers will be presented with many changes with airport interfaces after the pandemic. Touchless interfaces with ticketing devices and airport security not only lesson disease transmission, but also streamline throughput for an airport. A recent addition to the lexicon is the "frictionless" experience (Hernandez Bueno, 2021), which connotes not only better spatial physical travel, but less time spent queuing and partaking in other activities that contribute to a stressful travel experience for some.

Lastly, nations and international trade organizations will need to reconcile the issue of a vaccine passport. The ethical, moral, and public health issues surrounding this topic penetrate to the core of our individual societies. Because of this, there likely will never be a consensus approach among all member states of the international community. US airlines will have to decide if unvaccinated passengers fall into the category of those with an indiscernible medical condition and therefore fall under the protection of the American with Disabilities Act (Americans with Disabilities Act, 1990), or if they pose no greater harm than those with a temporary illness.

\section{THE FUTURE}

Trade organizations are in general consensus that the airline industry will take two to four years to fully recover from the Covid pandemic (Airlines for America, 2021; IATA, 2021). It is this author's opinion that the long-term will experience negligible consequences for the industry in the area of airport and aircraft cleanliness and increased hygienic standards; the rush to resume leisure travel and some aircraft operating at full capacity during the height of Covid was evidence that some of the traveling public is not dissuaded from travel because of these factors (Glusac, 2020).

The principal lesson to be gleaned likely will be that of resilience. What aviation entities harbored the adaptive capacity (Branlat \& Woods, 2010; Woods, 2018) to withstand an entire flock of black swans attacking at once? Did portions of the industry attempt to cling to decades-old prescriptive measures based on arbitrary standards imposed by a regulator, rather than the current safety science paradigm that promotes an evidence-based approach (Ge et al., 2019; Le Coze, 2020)?

\section{A. Sustainability}

The height of the pandemic saw extreme irony regarding the push in the past decade towards sustainability. A reduction in airborne aircraft meant more direct routing, including the eventual temporary suspension of the North Atlantic Tracks (NAT) in March of 2021 (Young, 2021). Airlines accelerated the retirement of less fuel-efficient airplanes (Knezevic, 2021), and airports were urged to take advantage of vacant landside and airside spaces to implement more energy efficient design (Tomber, 2020). Paradoxically, empty airplanes were being flown across oceans for the mere purpose of retaining slot rights at certain airports (McCartney, 2020), and aircraft were left running for weeks with auxiliary power units (APU) on vacant ramps.

Unfortunately, many efforts towards sustainability were put on hold during the Covid pandemic in lieu of basic survivability of the aviation sector. This suspension may have long-lasting effects, in that manufacturers may adopt a back-to-basics approach. Protecting essential research and development may be necessary, foregoing more capital-intensive projects that may be on the cutting edge and contribute to NextGen initiatives. 


\section{B. Airline Management}

Airline management will need to lean into the numerous issues that the Covid-19 pandemic presented. With the expectation that commercial aviation is an ultra-safe mode of transportation, is it acceptable to expose the traveling public to unvaccinated employees without their knowledge? The US has recently seen its airlines adopt incentive programs similar to that for weight management and smoking cessation, regarding the vaccination of their workforce (Abrams, 2021). It is unclear at this point if US airlines' fixation on vaccination for employees is based on a belief that the traveling public will trust travel if they feel employees are vaccinated, or more from a holistic health management perspective, lessening the burden on insurance claims.

The Covid pandemic saw most US airlines shed employees via early retirement programs. Now, the race has begun to hire the next generation of aviation professionals. The demographic shift will be unprecedented; cockpits will not be discussing steam gauges versus speed tape but rather if they have ever used ground-based navigation beyond an instrument landing system (ILS). Pressure will be put on training programs to increase throughput. The new generation of employees will be at ease with touch screen technology and electronic screen interface (Avsar et al., 2016). As a consequence, there may be pressure to increase distance training and a "learn by memo" culture.

\section{The Role of ICAO}

Recently, leaders of global institutions as well as some in academia have drawn parallels between the legacy of World War II and the Covid-19 pandemic. The World Health Organization's Director-General noted "the pandemic will cause more mass trauma than World War II and will have a longer lasting impact as well" (World Health Organization, 2021).

This observation is remarkable given the fact that 75 million people perished during World War II, yet current Covid fatalities are approximately 5 million as of September, 2021 (World Health Organization, 2021) . Although cited Covid deaths are $1 / 15$ th as that of World War II, this traumatic effect acknowledges that the pandemic's reach is irrespective of political or geographical borders, given the ubiquitous nature of media and our interconnected society.

For the aviation sector, the reference to World War II takes on increased significance. As fighting reached a crescendo in Europe in December of 1944 - the Battle of the Bulge as what Churchill called 'undoubtedly the greatest American battle of the war' (Churchill, 1945) - the Chicago Convention was being drafted in the United States, in what would become the architecture for the future International Civil Aviation Organization (ICAO). This was the most significant coalescence of nations in promotion of civil aviation in history. Its remarkable inception and prescience during one of the darkest hours in modern history is oftentimes overlooked.
Therefore, given the parallels to World War II and the longlasting effects the pandemic will have, might it be time to rethink the role of ICAO?

Macilree \& Duval (2020) recently analyzed the politics and geo-collaboration that has been observed during the pandemic. They note that both ICAO and IATA could be participating more robustly. Granted, both organizations have created userfriendly dashboards and produced robust data sets that help keep a scorecard for the pandemic's impact on aviation. Yet, compared to the courage that it took to create ICAO in 1944, is the same political will present to truly attempt to standardize disparate policy and implementation standards experienced during Covid that led to downstream disruptions to the airline industry? Some commentators have observed that the disjointed nature of Covid restrictions may be a harbinger for the realities of climate change: Could a type of aircraft be prohibited from a nation's airspace based on emission standards? These are big issues with no easy solution.

\section{IN CONCLUSION}

The Covid-19 pandemic gives us a once-in-a-multi generation opportunity to question many of the assumptions our aviation system is built upon, and recalibrate for the better.

This article provided a contextualization of the Covid-19 pandemic given past crises and attempted to elucidate a handful of pertinent issues that arose for the United States as we attempted to survive the crisis.

As the birthplace of aviation in 1903, the United States has been and will continue to be a leader globally in all areas of aerospace. Our outstanding safety record is due to collaboration and sharing of information irrespective of commercial fiefdoms. It is only in this spirit of collaboration and unity that both the US and global aviation industry will be able to emerge from the Covid-19 pandemic stronger and more resilient towards future challenges.

\section{REFERENCES}

Abate, M., Christidis, P., \& Purwanto, A. J. (2020). Government support to airlines in the aftermath of the COVID-19 pandemic. Journal of Air Transport Management, 89, 101931. https://doi.org/10.1016/j.jairtraman.2020.101931

Abeyratne, R. (2006). Implications of an Avian Flu Pandemic for Air

Transport. Air and Space Law, 31(3).

https://kluwerlawonline.com/journalarticle/Air+and+Space+Law/3

1.3/AILA2006017

Abiad, A., Arao, M., Dagli, S., Ferrarini, B., Noy, I., Osewe, P., Pagaduan, J., Park, D., \& Platitas, R. (2020). The Economic Impact of the 
COVID-19 Outbreak on Developing Asia (0 ed., ADB Briefs)

[ADB Briefs]. Asian Development Bank.

https://doi.org/10.22617/BRF200096

Abrams, A. (2021). Delta Will Charge Unvaccinated Employees \$200

Insurance Fee. Time. https://time.com/6093162/delta-coronavirusvaccine-insurance-charge/

Airlines for America. (2021). Impact of COVID-19: Data Updates. Airlines

For America. https://www.airlines.org/dataset/impact-of-Covid19data-updates/

ALPA. (2019). End the Carveout: All-Cargo Flight-Time/Duty-Time. Air Line Pilot. https://www.alpa.org/news-and-events/air-line-pilotmagazine/all-cargo-ft-dt

Americans with Disabilities Act. (1990). U.S. Department of Labor. https://www.dol.gov/general/topic/disability/ada

Avsar, H., Fischer, J. E., \& Rodden, T. (2016). Mixed method approach in designing flight decks with touch screens: A framework. 2016 IEEE/AIAA 35th Digital Avionics Systems Conference (DASC), 110. https://doi.org/10.1109/DASC.2016.7778066

Baas, J. G. (2020). Legislative Turbulence: 14 C.F.R. Part 117 and the "Cargo Carveout." Issues in Aviation Law and Policy, 20. https://trid.trb.org/view/1846324

Babbs, A. (2020). How to leverage data security in a post-Covid world. Computer Fraud \& Security, 2020(10), 8-11. https://doi.org/10.1016/S1361-3723(20)30107-X

Bartle, J. R., Lutte, R. K., \& Leuenberger, D. Z. (2021). Sustainability and Air Freight Transportation: Lessons from the Global Pandemic. Sustainability, 13(7), 3738. https://doi.org/10.3390/su13073738

Becken, S., \& Hughey, K. F. (2021). Impacts of changes to business travel practices in response to the COVID-19 lockdown in New Zealand. Journal of Sustainable Tourism, 0(0), 1-19. https://doi.org/10.1080/09669582.2021.1894160

Bhatti, A., Akram, H., Basit, H., Khan, A., Mahwish, S., Naqvi, R., \& Bilal, M. (2020). E-commerce trends during COVID-19 Pandemic. International Journal of Future Generation Communication and Networking, 13 .

Branlat, M., \& Woods, D. D. (2010). How Do Systems Manage Their
Adaptive Capacity to Successfully Handle Disruptions? A Resilience Engineering Perspective. Complex Adaptive Systems Resilience, Robustness, and Evolvability, 9.

Cenciarelli, O., Pietropaoli, S., Frusteri, L., Malizia, A., Carestia, M., amico, F., Sassolini, A., Di Giovanni, D., Tamburrini, A., Palombi, L., Bellecci, C., \& Gaudio, P. (2014). Biological Emergency Management: The Case of Ebola 2014 and the Air Transportation Involvement. Journal of Microbial and Biochemical Technology, 6, 247-253. https://doi.org/10.4172/1948-5948.1000152

Chung, L. H. (2015). Impact of pandemic control over airport economics: Reconciling public health with airport business through a streamlined approach in pandemic control. Journal of Air Transport Management, 44, 42-53. https://doi.org/10.1016/j.jairtraman.2015.02.003

Churchill, W. (1945, January 18). Prime minister Churchill's address in commons on relations among Britain, the U.S.A. and the U.S.S.R. The New York Times. http://www.ibiblio.org/pha/policy/1945/1945-01-18a.html

Derudder, B., \& Witlox, F. (2016). International Business Travel in the Global Economy. Routledge.

FAA. (2020). AC 120-66C - Aviation Safety Action Program. https://www.faa.gov/regulations_policies/advisory_circulars/index. cfm/go/document.information/documentID/1037363

FAA. (2021a). ASAP Participants. ASAP Policy \& Guidance.

https://www.faa.gov/about/initiatives/asap/media/asap_participants .pdf

FAA. (2021b). FAA Releases New PSA, Levies \$119K Against 9 Passengers for Alleged Unruly Behavior. https://www.faa.gov/newsroom/faareleases-new-psa-levies-119k-against-9-passengers-allegedunruly-behavior?newsId $=26300$

FAA. (2021c). Regulatory Updates due to Coronavirus [Template]. https://www.faa.gov/coronavirus/regulatory_updates/\#cargo

FAA. (2021d). Unruly Passengers. https://www.faa.gov/data_research/passengers_cargo/unruly_passe ngers/

Fedorik, M. (2021). Impacts of various critical situations on aviation industry 
and parallel with the COVID-19 pandemic.

https://dspace.cuni.cz/handle/20.500.11956/126565

Findlay, C., Roelfsema, H., \& Van De Wouw, N. (2021). Feeling the Pulse of

Global Value Chains: Air Cargo and COVID-19. Economic

Research Institute for ASEAN and East Asia (ERIA).

Ge, J., Xu, K., Zheng, X., Yao, X., Xu, Q., \& Zhang, B. (2019). The main challenges of safety science. Safety Science, 118, 119-125. https://doi.org/10.1016/j.ssci.2019.05.006

Gibbs, D. (2014). Colgan Air Accident-Driven Changes to Part 121 Flight Operations: It is Time for Phase Two (Editorial). International Journal of Aviation, Aeronautics, and Aerospace, 1(4).

https://commons.erau.edu/ijaaa/vol1/iss $4 / 2$

Glusac, E. (2020, July 21). Worried About Crowded Planes? Know Where Your Airline Stands. The New York Times.

https://www.nytimes.com/2020/07/21/travel/crowded-flightscoronavirus.html

Haines, A. (2021). Ryanair to appeal EU court's decision on French and Swedish state aid. International Tax Review. https://www.proquest.com/openview/575cc31691302ab34a9ed15f a3b232d6/1?pq-origsite $=$ gscholar\&cbl $=30282$

Hernandez Bueno, A. V. (2021). Becoming a passenger: Exploring the situational passenger experience and airport design in the Copenhagen Airport. Mobilities, 16(3), 440-459. https://doi.org/10.1080/17450101.2020.1864114

Herrman, J. (2019, November 13). We're Stuck With the Tech Giants. But They're Stuck With Each Other. The New York Times. https://www.nytimes.com/interactive/2019/11/13/magazine/interne t-platform.html

IATA. (2020a). Weak Air Freight Demand Continues. https://go.updates.iata.org/webmail/123902/1160675010/f9ec1ad9 549090c8b11266c01ffb068968c74bffd095aafle8eb3523195363fc

IATA. (2020b). What can we learn from past pandemic episodes? https://www.iata.org/en/iata-repository/publications/economicreports/what-can-we-learn-from-past-pandemic-episodes/

IATA. (2021). Airline Industry Financial Forecast. https://www.iata.org/en/iata-repository/publications/economic- reports/airline-industry-economic-performance---april-2021--report/

Knezevic, J. (2021). COVID-19 Pandemic as a Mechanism of the Motion of an Aircraft in MIRCE Mechanics. American Journal of Engineering and Technology Management, 6(1), 1. https://doi.org/10.11648/j.ajetm.20210601.11

Landsberg, B. (2014, May 12). Safety Pilot Landmark Accident: Unintended consequences [Text]. https://www.aopa.org/news-and-media/allnews/2014/december/pilot/landmark

Le Coze, J. C. (2020). Ideas for the future of safety science. Safety Science, 132, 104966. https://doi.org/10.1016/j.ssci.2020.104966

Lee, D. (2021, September 1). Amazon now running 164 flights a day to deliver stock in US. Financial Times. https://www.ft.com/content/ec355eb5-8dbd-4293-9a21$46 \mathrm{fc} 09 \mathrm{~d} 2 \mathrm{ed} 2 \mathrm{~d}$

Macilree, J., \& Duval, D. T. (2020). Aeropolitics in a post-COVID-19 world. Journal of Air Transport Management, 88, 101864. https://doi.org/10.1016/j.jairtraman.2020.101864

McCartin, J. (2006). PATCO, Permanent Replacement, and the Loss of Labor's Strike Weapon. Perspectives on Work, 10(1), 17-19. McCartney, S. (2020). Why Empty Planes Keep Flying Through the Pandemic. Wall Street Journal. https://www.wsj.com/articles/whyempty-planes-keep-flying-through-the-pandemic-11588771233

McLinton, S. S., Drury, D., Masocha, S., Savelsberg, H., Martin, L., \& Lushington, K. (2020). “Air rage”: A systematic review of research on disruptive airline passenger behaviour 1985-2020. Journal of Airline and Airport Management, 10(1), 31-49. https://doi.org/10.3926/jairm.156

NTSB. (2019). Rapid Descent and Crash into Water Atlas Air Inc. Flight 3591. https://www.ntsb.gov/investigations/Pages/DCA19MA086.aspx

Patalano, R. (2017). September 11th, an attack at the limits of thought. The International Journal of Psychoanalysis, 98(5), 1359-1384. https://doi.org/10.1111/1745-8315.12579

Rae, A., Provan, D., Aboelssaad, H., \& Alexander, R. (2020). A manifesto for Reality-based Safety Science. Safety Science, 126, 104654. 
https://doi.org/10.1016/j.ssci.2020.104654

Salerno, R. (2017). The Downsizing and Dying of $C V G$.

https://ronnysalerno.com/queencitydiscovery/2012/08/the-

downsizing-and-dying-of-cvg.html

Shostak, A. (2006). Finding Meaning in Labor's "Perfect Storm": Lessons from the 1981 PATCO Strike. Employee Responsibilities \& Rights Journal, 18(3), 223-229. https://doi.org/10.1007/s10672-006$9020-0$

Sønderby, K. (2016). How can aviation regulators retain effectiveness in a performance-based environment? http://lup.lub.lu.se/studentpapers/record/8309632

Suau-Sanchez, P., Voltes-Dorta, A., \& Cugueró-Escofet, N. (2020). An early assessment of the impact of COVID-19 on air transport: Just another crisis or the end of aviation as we know it? Journal of Transport Geography, 86, 102749.

https://doi.org/10.1016/j.jtrangeo.2020.102749

Sun, X., Wandelt, S., Zheng, C., \& Zhang, A. (2021). COVID-19 pandemic and air transportation: Successfully navigating the paper hurricane. Journal of Air Transport Management, 94, 102062.

https://doi.org/10.1016/j.jairtraman.2021.102062

Tang, R. Y. (2020). CARES Act Payroll Support to Air Carriers and

Contractors. 3.

Tomber, D. (2020). Consider "Inspansion” During COVID-19 Recovery.

Airport Improvement Magazine.

https://airportimprovement.com/consider-inspansion-during-

Covid-19-recovery

Traynor, T. L., \& Fichtenbaum, R. H. (1997). The Impact of Post-Patco Labor Relations on U.S. Union Wages. Eastern Economic Journal, 23(1), $61-72$.

U. S. Government Accountability Office. (2021). COVID-19 Pandemic:

Preliminary Observations on Efforts toward and Factors Affecting the Aviation Industry's Recovery.

https://www.gao.gov/products/gao-21-412t
Van Doren, C. S. (1993). PAN AM's Legacy to World Tourism. Journal of Travel Research, 32(1), 3-12. https://doi.org/10.1177/004728759303200102

Van Wee, B., \& Roeser, S. (2013). Ethical Theories and the Cost-Benefit Analysis-Based Ex Ante Evaluation of Transport Policies and Plans. Transport Reviews, 33(6), 743-760. https://doi.org/10.1080/01441647.2013.854281

Weise, K. (2021, April 29). Amazon's profit soars 220 percent as pandemic drives shopping online. The New York Times. https://www.nytimes.com/2021/04/29/technology/amazons-profitstriple.html

Wiesner, H. (2021). Inbound air freight prices go sky high in the midst of pandemic: Beyond the Numbers: U.S. Bureau of Labor Statistics. Bureau of Labor Statistics. https://www.bls.gov/opub/btn/volume10/air-freight-prices.htm

Wilson, K. (n.d.). Investigating Human Fatigue Factors - A Tale of Two Accidents. National Transportation Safety Board. Retrieved September 5, 2021, from https://isasi.org/Documents/library/technicalpapers/2015/Wilson_Investigating\%20Human\%20Fatigue\%20Fact ors.pdf

Wood, D. (2021). Flight Attendant Union Sends Letter to Southwest Airlines CEO After Vicious Assault. Hospitality Trade Journal. https://vtechworks.lib.vt.edu/handle/10919/103496

Woods, D. D. (2018). The theory of graceful extensibility: Basic rules that govern adaptive systems. Environment Systems and Decisions, 38(4), 433-457. https://doi.org/10.1007/s10669-018-9708-3

World Health Organization. (2021). WHO Coronavirus (COVID-19) Dashboard. https://Covid19.who.int

Young, J. (2021). NATS records first day with zero westbound North Atlantic tracks. NATS Blog. https://nats.aero/blog/2021/03/nats-recordsfirst-day-with-zero-westbound-north-atlantic-tracks/ 